\title{
WAR DAMAGE COMPENSATION THROUGH REHABILITATION: THE PHILIPPINE WAR DAMAGE COMMISSION
}

\author{
ERNEST SCHEIN* \\ I \\ War Claims-A General Survey
}

The palm which fashions war claims has a long life-line. Complications arising out of each destructive struggle appear almost to merge with the heated problems of the next. At this moment when the victims of World War II might be finding some encouragement from the progress of international negotiations and domestic legislation, vast areas of the still smoldering world are being devastated anew, creating grievances of greater and greater weight and complexity.

The dual question: (a) What constitutes a war claim and (b) What are the standards upon which it will be adjusted, cannot be answered categorically; but in developing the subject of this study, some of the attempts at its solution should be reviewed and discussed.

\section{A. What Are War Damages?}

When reference is made to war claims or war damages in treaties and domestic legislation, what is contemplated is the kind of loss for which compensation must be considered. Under the harsh rules of war, injuries derived from sanctioned military activity are not ordinarily accompanied by rights to relief. Compensable war losses result chiefly from requisition, seizure, detention, sequestration, confiscation, use, and destruction outside what is recognized as excusable incidents of hostility. Provision has been made for claims based upon torts, broken contracts, even loss of profits, interest, expenses and costs. The property involved may be real or personal, merchandise, commodities, household furniture, and clothing. In recent efforts to define the substance of loss for which reimbursement should be made, the American, British, French and Dutch governments have not undertaken to include currency or intangible property, and either have excluded completely or provided for in only limited amounts, articles of jewelry, works of art, and other luxuries.

In general, claims arising out of World War II will be defined by (a) international agreements, treaties, conventions, and exchanges of notes; (b) domestic law; (c) implicit principles, sometimes called the common international law, which govern the behavior of civilized nations. 1

- A.B. 19r9, LL.B. I922, Harvard University. Member of the Illinois and District of Columbia bars. Formerly Chief of the Philippine Division of United States Commercial Company (F.E.A. and R.F.C.) and Chief of Publie and Private Claims of the Philippine War Damage Commission:

${ }^{1}$ In this connection an applicable interpretation of the meaning of international law is found in Borchard, The Place of Law and Courts in International Relations, 37 AM. J. INT'L L. 46, 54-55 (I943): 'International law is a system of normative rules, developed most actively from the seventeenth century 
In the legislation of the United States, as well as allied countries, war damage has been defined very broadly. The recent report of the War Claims Commission points out that Congress deliberately omitted defining the term war claims under Section 8 of the War Claims Act rather than assume the risk of adopting a narrow definition. It was left to the Commission to make a study and at its end to recommend what claims should or should not be considered. ${ }^{2}$

\section{B. What Are the Standards Upon Which War Claims Are Settled?}

The creation and ultimate settlement of war claims during their long history have given rise to acknowledged principles which form a pattern or set of ground rules which are reliable in making the simplest adjustments. Thus, since during a war a belligerent government admittedly cannot take the time and trouble to buy all the property which it needs in emergencies, indiscriminate requisitioning becomes an accepted procedure, and requisition is always accompanied by the duty to make proper compensation to the owner. ${ }^{3}$

to the early twentieth, which obtain their sanction not by force but by practice and cultivation among governmental authorities-state executives, ministers of foreign affairs, other public officials, and notably international tribunals of various kinds. Narrow as may be its scope in the total complex of international relations, and in constant danger of submersion or violation of politics, it nevertheless controls a vast field of human activity and is universally invoked both by governments and by individuals affected. Few violations escape public notice, and while the sanctions necessarily differ from those of private law, they nevertheless operate with considerable efficacy. States may differ as to what is the rule of international law, but no State would ever assert exemption from its control."

${ }^{2}$ War Claims Aict of 1948, 62 STAT. 1240, 50 U. S. C. App. \$\$2001-2013 (Supp. 1950). The tcrm "war claims" in pursuance of the authority given by Congress was defined by the administrative regulations of the War Claims Commission as follows:

"War Claims.-Shall include any loss, injury, or damage suffered or sustained by a person or business entity or organization, who, at the time of such loss, injury, or damage, was:

(a) a national of the United States, as hereinafter defined, who did not give aid or comfort to, or collaborate with any enemy or ally of enemy of the United States; or a branch or agency of the United States Government; or a regularly appointed, enrolled, enlisted, or inducted member of the military or naval forces of the United States; or an alien to whom the United States owes protection, such as an alien seaman signed on a United States vessel. Such loss, injury, or damage must be the result of action, not normally incident to the conduct of hostilities, by a branch or agency, civil or military, of any sovereign power who, by declaration of war or by military activity of its regular forces, was at war during World War II, such loss, injury, or damage being one which would not have cecurred, but for the existence of a state of war; or

(b) not a national of the United States and not an enemy, or ally of enemy, as defined in section 2 of the Trading With the Enemy Act of 1917 (50 U. S. C. App. \$2): Provided, That such definition shall not apply to a person who, after September 1, 1939, being resident within enemy or ally of enemy territory, or being a citizen or subject of such enemy or ally of enemy nation, was deprived of liberty, or did not enjoy full rights of citizenship under the laws of such enemy or ally of enemy nation, as a consequence of any law, decree or regulation, of the nation within which he resided, or of which he was a citizen or subject, discriminating against political racial or religious groups. Such loss, injury, or damage must be the result of an action, not normally incident to the conduct of hostilities, by" the Government of the United States or one of its civil or military agencies. Such action must arise out of World War II and the loss, injury, or damage must be one which would not have occurred but for the existence of 2 state of war." (pp. 5,6 .)

${ }^{3} 2$ Marjorie M. Whiteman, Damages in International LAw 902 (1937). United States Army Rules of LAND WARFARE, \$331: "Private property susceptible of direct military use.-All appliances, whether on land, at sea, adapted for the transmission of news, or for the transport of persons or things, exclusive of cases governed by naval law, depots of arms, and generally all kinds of ammunition of war, may be seized, even if they belong to private individuals, but must be restored and compensation fixed when peace is declared (H. R. 53, par. 2)." 
On the other hand, reimbursement for the loss of prospective profits, interest, intangibles, money, luxuries, presents controversial elements to those endeavoring to meet demands for international understanding and domestic or unilateral legisla. tion.

When liability is acknowledged, the measure of damages in claims of various categories has been considered but not always adequately dealt with in the making of awards. After World War I, the United States-Germany Mixed Claims Commission applied the following rule in the evaluation of plants and going concerns:

In computing the reasonable value of plants and other properties at the time of their destruction, the nature and value of the business done, their earning capacity based on previous operations, urgency of demand and readiness to produce to meet such demand which may conceivably force the then market value above reproduction costs, even the goodwill of the business, and many other factors, have been taken into account. But this is quite a different thing from assessing damage for loss of prospective earnings or profits for a period of years computed arbitrarily or according to the earnings of competitors whose properties were not destroyed, and the awards made by this Commission do not embrace the items claimed of prospective earnings or prospective profits. ${ }^{4}$

The Special Mexican Claims Commission in its first decision describes the measure of damages which it employed in claims for loss or damage of property, as follows:

The quantity and value of property of various kinds owned by the claimant as shown by inventories filed prior to the origin of the claim; the market value, original cost, and depreciation of the property; and deterioration through lack of attention directly attributable to acts of force. In this connection the Commission has applied the principle that, where the evidence does not satisfactorily establish a high or unusual value for property, an award should be made on the basis of the value of common or ordinary property of that class.

Miss Whiteman in her work, after a review of the subject of damages in international reclamation proceedings, wisely concludes:

It will be evident from the context of the decisions in the various cases that the amount allowed in any case should be that to which the claimant is reasonably entitled under all the circumstances. ${ }^{6}$

An additional standard to be followed in the making of awards determines whether the claimant is qualified to receive settlement. Specifically, should war damages be paid by a country only to its own nationals or to the nationals of allies, or even of neutrals, who suffered losses in their territories? ${ }^{7}$

Assuming that the appropriate claimant is identified, the basis of loss recognized,

- Decisions and Opinions of the United States-Germany Mixed Claims Commission 273, 308, 33 704 (1925-1926).

"Special Mexican Claims Commission, Report to the Secretary of State 2 i (i940).

- Whuteman, op. cit. supra, note 3 , at 1549 .

${ }^{7}$ A valuable study of this subject appears in Fraleigh, Compensation for War Damage to American Property in Allied Countries, $4 \mathrm{I}$ AM. J. INT'L L. 748 (1947). 
and the measure of damages established, the question still remains: what effect has the compensation upon the rehabilitation of the country in which the war loss has been sustained? It is submitted that underlying the philosophy of equitable adjustment of losses incurred by victims of war is the ethical requirement that society should be restored after damage inflicted by belligerents. In provisions for indemnity or reparations, restitution in kind has always been an objective pursued where practically feasible. A systematic search for looted property follows the repulse of the enemy. There is universally prevalent a feeling for putting together the pieces which have been shattered by the forces of war.

Whatever method of claims settlement is finally adopted, the awards will be made principally by judicial boards or commissions. ${ }^{8}$ Even if lump sum settlements in cash are negotiated between countries, the claims themselves will have to be adjudicated and the monies distributed by a commission or arbitral body. The settlement of claims of the United States Government and nationals against the government of Yugoslavia arising from the nationalization of properties for an amount of approximately seventeen million dollars was accompanied by the adoption of the International Claims Settlement Act of 1949 which established a Commission to make awards. ${ }^{9}$

Save in claims for breach of contract or the seizure of property through requisition, confiscation, nationalization, expropriation or other seizure-in short, except in those cases which are analogous to suits for the recovery of money-the trend in thinking about war damage compensation is towards rehabilitation. Even when claim for claim in connection with the loss of property in a war-devastated area is considered, it is total rehabilitation which is set as a goal. As in the physical rehabilitation of individual soldiers, the responsibility of the group dominates, so in the award of war damages, the aggregate restoration of what has been physically devastated, economically destroyed or damaged, must be dealt with on a country-wide or even area-wide basis.

Legislation of the United States dealing with the rehabilitation of the Philippines represents an historical accomplishment, as well as a guide for future undertakings of other interested states. Since this study will further concern itself only with the relation of war claims and war damage compensation to rehabilitation, the Philippine Rehabilitation Act of $194^{1 \theta}$ and the work of the Philippine War Damage Commission will be examined in some detail as valuable contributions to the development of the subject.

\footnotetext{
- Aside from the numerous Mixed Arbitral Tribunals created under the Treaties of Peace of 1919-1920, some sixty such tribunals have functioned during the past hundred years. MANLEY $O$. Hudson, INrRRnational Tribunals, Past and Future 196 (1944).

'International Claims Settlement Act, Pub. L. No. 455, 81st Cong., 2d Sess. (1949).

${ }^{10}$ Philippine Rehabilitation Act of 1946, Go Stat. x28, 50 U. S. C. App. \$\$1751-1806 (1946).
} 
II

\section{Phimippine Rehabilitation-A Specific Case History}

\section{A. Background}

President Roosevelt only voiced the sentiments of many other Americans when he told the people of the Philippines that they would get back everything they lost in the war to the last nipa hut and the last carabao. War damage compensation, strictly construed, became absorbed in the concept of rehabilitation, and traditional legal grounds for the collection of claims under international law yielded to the pressure of what was a whole nation's humane viewpoint.

The American who suffers war damage to property on territory of the United States during a war knows that compensation somehow will be provided by his own government. Specifically in providing for losses in World War II, an Act of Congress of March 27, 1942, ${ }^{11}$ authorized and directed the War Damage Corporation to provide premium insurance effective not later than July I, 1942, against war losses, with such general exceptions as the War Damage Corporation, subject to approval of the Secretary of Commerce, might deem advisable. Coverage was not extended to property in the Philippine Islands, however, because lack of control by the United States made protection impracticable during the period of occupation by the Japanese.

The Act further expressly provided that subject to the same limitations prescribed with respect to premium insurance, the War Damage Corporation might compensate for losses after December 6, I94I and prior to the effective date of the premium insurance program, July I, I942, without requiring a contract of insurance or the payment of premiums. The free insurance, of course, terminated automatically on July $\mathrm{I}$, 1942 .

By September 30, 1944, claims and notices of contingent or prospective claims, totalling 393 in number and property values of more than one hundred thirty-five million dollars, alleged to have risen in the Philippine Islands prior to July I, 1942, had been presented to the War Damage Corporation. No payments were made, both because of the inaccessibility of the area for purposes of investigation and adjustment, and the general sentiment that Congress wished to deal with the subject on a special basis when the occasion arose.

Early in 1945, it was proposed to amend Section 5(g) of the Reconstruction Finance Corporation Act relating to the War Damage Corporation respecting losses in the Philippine Islands ${ }^{12}$ in two major respects: (I) to broaden the definition of war damage; (2) to extend automatic free insurance on property in the Philippine Islands (with designated exceptions) beyond the date of July $\mathrm{r}$, 1942.

During the Senate hearings on the proposal, a letter from Mr. Jesse Jones, then Chairman of the Reconstruction Finance Corporation, to Senator Millard Tydings, Chairman of the Committee on Territories and Insular Affairs of the United States

${ }^{12}$ Pub. L. No. 506, 77th Cong., 2nd Sess. (r942).

12 S. 104, 79th Cong., Ist Sess. (1945). 
Senate, dated December 4, I944, was read. ${ }^{13}$ Among other things, Mr. Jones stated:

To summarize, it seems to me that Congress should enact legislation with respect to the overall Philippine situation and should provide for the payment of appropriate compensation for property damage due to combat operations in the Islands throughout the period of enemy attack, encmy occupation and our reoccupation. Since such compensation will have close connection with general relief and rehabilitation in the Philippines, it may be that Congress would want the whole Philippine problem handled by a Filipino Rehabilitation Commission, the members to be appointed by the President and approved by the Senate. $^{14}$

It appeared further in the course of the proceedings before the Committee on Territories and Insular Affairs that the United States Army in the Philippines took for its own use during the emergency considerable private property without being able to follow formal procurement procedures. Claims for such property, even if informally appropriated, could be paid out of customary War Department appropriations. However, claims for property destroyed to prevent capture by the enemy, which was a common practice, were not payable from available funds or under established regulations.

The Commanding General of the United States Armed Forces in the Far East had already organized a Claims Service in the Philippine Islands for the settlement of contract or procurement claims as well as torts. ${ }^{15}$ That such claims should be settled as promptly as possible was considered not only a military necessity, but politically expedient in promoting friendly relations with the inhabitants.

The adjustment of losses as a military measure fell short of what we proposed to do for the Philippines. Moreover, the payment of claims for damages on the basis of insurance adjustments appeared woefully inadequate. The terms of the proposed bill to change the War Damage Corporation's powers, it was admitted, did not approach our goal, even on a limited basis. For instance, losses of office buildings, factories, and mechanical installations, were covered, but compensation was

${ }^{23}$ Report of Proceedings, Hearings before Senate Committee on Territories and Insular Affairs on S. 104, 79th Cong., Ist Sess. (1945).

14 The Act of March 7, I942 (Pub. L. No. 506, 77th Cong., 2d Sess. (1942)) provides in part as follows: "Such protection shall be applicable only (I) to such property situated in the United States (including the several states and the District of Columbia), the Philippine Islands, the Canal Zone, the territories and possessions of the United States, and in such other places as may be dutcrmined by the President to be under the dominion and control of the United States. . . The War Damage Corporation, with the approval of the Secretary of Commerce, may suspend, restrict, or otherwise limit such protection in any area to the extent that it may determine to be necessary or advisable, in consideration of the loss of control over cuch area by the United States, making it impossible or impracticable to provide such protection in such area."

${ }^{15}$ As to service-connected tort claims resuiting from noncombat activitics of the Army: Under the provisions of the Act of July 3, I943 (57 STAT. 372, 31 U. S. C. \$222b (1946)), the War Department is authorized to settle claims on account of damage to or loss or destruction of property, and reasonable hospital, medical and burial expenses actually incurred on account of personal injury or death caused by Army personnel acting within the scope of duty or otherwise incident to noncombat activities of the Army. Under the provisions of AR 25-25, the Army regulations implementing the provisions of the act of July 3, I943, the War Department does not pay claims for damage to or loss or destruction of property or for personal injury or death resulting from action by the enemy or resulting directly or in. directly from any act by the Armed Forces engaged in combat. 
specifically excluded for growing crops, orchards, personal apparel, and household furniture, which obviously formed the aggregate of the wealth of a simple Filipino family.

More than anything else, the reluctance of the Senate Committee to act along traditional lines was prompted by the conviction that ordinary war damage compensation went only a short distance towards actual rehabilitation-the rebuilding of the physical equipment and economy of a country despoiled by war. It was decided to refer S. I04 to the Philippine Rehabilitation Commission, ${ }^{16}$ with a request that they examine the requirements and report back a program which would be a constructive solution of the Philippine problem.

No measure was ever projected by the Congress which was intended primarily to reimburse individuals or organizations for specific damages incurred in the war. The aim was to assist and encourage rehabilitation, the rebuilding of the physical, economic and social structure of the Philippines. The bill, S. 16ro, introduced in the Senate for the purpose of attaining these high purposes, suffered the usual legislative vicissitudes, in the course of which the original objectives of the proposed law became confused and distorted.

The first conception, as has been indicated, was not a private class measure for the payment of war losses. In attempting to provide for practical implementation, however, this type of measure dominated the thinking of the law-makers. There was no denying the influence of the procedures of the past. Claims commissions, international, national or other arbitral bodies, had always awarded compensation determined according to certain standards. Therefore, a commission had to be set up, the duties and responsibilities of which comprised a mixture in which direct rehabilitation was only one ingredient. Economy-minded and high-principled public servants laid the greatest emphasis upon the setting up of standards to minimize fraudulent practices which might be costly to our Treasury and a menace to our moral code.

The Philippine Rehabilitation Act ${ }^{17}$ emerged with the word "rehabilitation" in its title and with very substantial provisions for the assistance of the Philippine rehabilitation program. However, its language from the very beginning refers generously to "compensation for war damage." The agency which it established is known as the Philippine War Damage Commission, the discharge of its duties embracing a combination of welfare payments to the lowly, adjustment of losses-analogous to the payment of insurance benefits-to more substantial property owners, and the granting of funds which contributed in part to the overall program of physical rehabilitation adopted by the Republic of the Philippines.

\footnotetext{
${ }^{10}$ Created by Act of Congress approved June 29, 1944. For a summary of pertinent legislation, see Harky Barto Hawes, Rehabilitation of the Phlippines (I944).

${ }^{17}$ Philippine Rehabilitation Act of 1946, 60 StAт. 128, 50 U. S. C. App. \$\$1751-r806 (1946).
} 


\section{B. The Philippine Rehabilitation Act of 1946}

\section{Title I- War Damage Compensation}

The Philippine War Damage Commission consisted of three members. ${ }^{18}$ The time limit of its functions was set at two years after the expiration of the time for filing claims, and in no event later than five years from the eaactment of the Act, which was April 30, 1946. ${ }^{19}$

The Commission was charged with the functions of receiving, investigating, approving, and disapproving war damage claims covering properties lost, destroyed or damaged during and as a consequence of World War II in the Philippines, and of making payment, replacement or restitution for such loss in accordance with the law. In exercising these functions, the authority of the Commission is in lieu of and supersedes that which was previously conferred on the War Damage Corporation. ${ }^{20}$

Losses to be considered by the Commission must have been the result of one or more of the following: (I) enemy attack; (2) action taken by or at the request of the forces of the United States to prevent property from coming into the possession of the enemy; (3) action taken by civilian or military representatives of enemy or governments cooperating with it; (4) action of the Armed Forces of the United States in opposing, resisting or expelling the enemy; (5) looting, pillage or other lawlessness or disorder accompanying the collapse of civilian authority determined by the Commission to have resulted from any of the other perils or from control by enemy forces. ${ }^{21}$

Qualified claimants are (I) those who have an insurable interest in the property alleged to be lost, as owner, mortgagee, pledgee or lien holder; (2) any heir, devisee, legatee or distributee of a deceased person's interest; (3) executor or administrator of the estate of a deceased person for the benefit of such heir, devisee, legatee or distributee. The claimants must come under one of the following categories: (a) a citizen of the Philippines or the United States on December 7, I94I and continuously to the date of filing claims; or (b) a citizen of a nation not an enemy of the United States in World War II, if he had been a resident of the Philippines at least five years prior to December 7 , I94I, provided that the country of which he is a citizen grants reciprocal war damage payments to American citizens resident therein; or (c) a person who served honorably in the Armed Forces of the United States or Commonwealth of the Philippines or the Merchant Marine; or (d) a church or religious organization; or (e) an unincorporated association, trust or corporation (or their successors if already dissolved), organized pursuant to the laws of the several states of the United States or territory or possession, including those

${ }^{18}$ Filipino member is Francisco A. Delgado; American member John Young was succeeded by John A. O'Donnell; Frank A. Waring was the chairman.

${ }^{10} 60$ STAT. 128, 50 U. S. C. App. \$I75I(d) (1946).

20 60 Stat. 129, 132, 50 U. S. C. App. \$\$1752, 1759 (1946).

$=260$ STAT. I29, 50 U. S. C. App. §i752(a) (I946). 
organized pursuant to the laws in effect in the Philippines, but excluding corporations wholly owned by the Philippines. ${ }^{22}$

Specifically disqualified from receiving war damage compensation are: (I) enemy aliens; (2) collaborators and disloyal persons; (3) any unincorporated association, trust, corporation or sociedad anomima owned by any such persons. Payment is barred ( $I$ ) if loss or damage to the property was insured, except for the excess of the value over the face value of the insurance; or (2) if the loss or damage is one for which the War Department or Navy Department is authorized to make payment; or (3) if the loss or damage is payable or has been paid or is authorized to be paid by the Government of the United States or the Government of the Philippines, unless such payment was declined; or (4) if the claimant does not file a claim in reasonable conformity with the law within twelve months after the opening date set by the Commission for filing.

All property is subject to compensation, except the following (in general): ( $I$ ) Accounts, bills, records, films, plans, drawings, formulas, currency, deeds, evidences of debts, securities, money, bullion, furs, jewelry, stamps, precious and semi-precious stones, works of art, antiques, stamp and coin collections, manuscripts, books and publications more than fifty years old, models, curiosities, objects of historical or scientific interest, and pleasure aircraft, unless such are included in inventory, supplies or equipment for carrying on a trade or business within the Philippines; (2) vessels and watercraft, their cargoes and equipment, with certain exceptions; (3) intangible property; (4) property diverted to the Philippines by authority of the United States Government, or otherwise as the result of war conditions; (5) property in transit which was insured against war perils or with respect to which insurance was available. ${ }^{23}$

Claims are provable either for (a) actual cash value at the time of loss or destruction or damage; or (b) the actual cost of repairing or rebuilding or replacing with other property of like quality, whichever is less. ${ }^{24}$ In lieu of cash payments, the Commission may, at its option, make payments in whole or in part of the amount payable by replacing lost, damaged or destroyed property with any other property of like or similar kind; and the Commission is authorized to acquire such property, to have such work done, to make contracts, and to take such other action as may be necessary for the purpose; and surplus property of the United States may be transferred to the Commission at a fair valuation, to be used in settling claims. ${ }^{25}$

Before payments are actually made to claimants, the Commission is directed to require that lost, destroyed or damaged property be rebuilt, replaced or repaired, provided that in the event that the Commission determines that it is impracticable to do this, payments may be made subject to the further requirement that they be

\footnotetext{
2260 STAT. I29, 50 U. S. C. App. \$I752 (I946).

${ }^{23} 60$ STAT. I33, 50 U. S. C. App. $\$ 1760$ (1946)

${ }^{24} 60$ STAT. 129, 50 U. S. C. App. \$1752 (1946).

${ }^{28} 60$ STAT. I30, as amended, 60 StAт. 805, 50 U. S. C. App. $5 \times 754$ (b) (1946).
} 
reinvested in such manner as will further the rehabilitation or economic development of the Philippines. ${ }^{26}$

Claims up to $\$ 500$, those of the little man, were to be paid in full and as quickly as allowed. ${ }^{27}$ Of larger claims, the excess above $\$ 500$ is arbitrarily reduced by 25 per cent. ${ }^{28}$ A pro rata, not exceeding 80 per cent, applicable to all claims, was authorized to be paid immediately upon allowance. Remaining funds are to be distributed pro rata among allowable claims. ${ }^{29}$

The War Damage Commission notifies the claimants of the approval or disapproval of their claims, and dissatisfied claimants are entitled to a hearing on appeal before the Commission, or its representatives, under such rules and regulations as may be prescribed, the decision of the Commission to be final and not reviewable by any court. ${ }^{30}$

Penalties are provided for fraud ${ }^{31}$ and a 5 per cent limit is placed on fees. ${ }^{32}$

The total authorization of Congress for the payment of private claims was four hundred million dollars. Of this amount twelve million dollars ear-marked for administrative expense will probably not be exhausted by the Commission. ${ }^{33}$

Money or bullion received by the United States from Japan is to be used ( $\mathrm{x}$ ) to reimburse the Treasury for sums appropriated; (2) to satisfy unpaid balances of approved claims; (3) to make up the 25 per cent by which claims were first reduced; (4) to pay any approved claim of the Philippine Government or its subsidiaries not compensated under the Act. The balance will also be covered into the Treasury of the United States. ${ }^{34}$

\section{Title II-Disposal of Surplus Property}

To expedite the disposition of surplus property of the United States in the Philippines as well as to aid in physical rehabilitation, there was transferred to the Government of the Philippines, provinces, chartered cities, and municipalities, property of a fair value, estimated by the Foreign Liquidation Commissioner, not to exceed one hundred million dollars. ${ }^{35}$

\section{Title III-Restoration and Improvement of Public Property and Essential Public Services}

As a manifestation of good will to the Filipino people, appropriations of one hundred twenty million dollars were approved for the following purposes: (I) to plan, design, restore, and build roads, streets, and bridges, and to train ten Filipino engineers in the construction, maintenance, and engineering necessary for efficient and safe operation of highway transport facilities; (2) to rehabilitate and improve port and harbor facilities and to train ten Filipino engineers for this work; (3) to compensate the national Philippine Government, provincial governments, chartered

\footnotetext{
${ }^{28} I d . \$ \times 754$ (c).

${ }^{20} I d$. $\$ 1754$ (a).

${ }^{2 \pi}$ Id. $\$ \mathrm{I} 754(\mathrm{a})$.

${ }^{28}$ Id. $\$ 1752(\mathrm{a})$.

se $I d . \$ 1758$.

${ }^{30} \mathrm{Id}$. $\$ \mathrm{I}_{7} 63$. $\quad$ "Id. $\$ 1757$.

${ }^{33} I d$. $\$ 7756(2)$. The original allowance for administrative expense of $\$ 4$ million was incredsed.

${ }^{34} I d$. $\$ 1756(\mathrm{~b})$.
} 
cities, municipalities and corporations wholly owned by the Government, for physical loss or damage to public property during and as a result of the war; (4) to help in the rehabilitation and development of public health services. ${ }^{36}$

Appropriate agencies of the United States are designated to assist in directions within their respective jurisdictions towards the goal of complete rehabilitation. The restoration and improvement of inter-island commerce is assigned to the Maritime Commission; air navigation to the Civil Aeronautics Administration; meteorological equipment to the Weather Bureau; the fish industry to the Department of the Interior; coast and geodetic survey to the Commerce Department. In all instances the training of Filipino specialists is emphasized. ${ }^{37}$

\section{Titles $I V, V$, and $V I$}

The Act contains general provisions incidental to its execution. Rehabilitation is involved directly only in the authorization of the expenditure of five million dollars for the restoration, repair, and improvement of public buildings of the United States and the acquisition of housing for civilian agencies in the Philippines. ${ }^{38}$ It was under the last general power that the War Damage Commission procured efficient space in specially constructed buildings which at the end of its program will become the possessions of the Republic of the Philippines.

\section{Experience of the Philippine War Damage Commission}

Time and space have been given liberally to a summary of the organic act of Philippine rehabilitation since from this more than anything else can the essential inconsistencies of the undertakings of the War Damage Commission be evaluated. Moreover, it brings into focus a rehabilitation program, based on the principle of war damage compensation, ideally conceived, but implemented by legislation the detailed provisions of which are fraught with weaknesses inherent in considerations of politics, nationalism, and narrow legal traditions. For further enlightenment.and possible practical assistance in future undertakings with like objectives, we may direct our attention profitably to some of the experiences of the Commission which even as this paper is being written hastens towards the completion of its difficult and significant assignment.

The challenge and danger of the task of the War Damage Commission were first posed in the assembling of staff personnel in the United States. Although the law specifically excluded any regard to the civil service laws or the Classification Act of x $^{23}$, as amended, ${ }^{39}$ it was to be expected that Commissioners, fabricating what they perceived as another government agency, should call upon civil service experts for advice in employment procedures, and follow, as far as practicable, the routine established in other departments. The advantages in regularity are obvious, but so are shortcomings in the direction of elasticity of employment, transfers, and separations which the legislators in fact sought to avoid.

\footnotetext{
${ }^{26} I d . \S \S I 78 x-1785$.

${ }^{\text {so } I d . ~} \$ \$ 1796-1797$, . $80 \mathrm{r}, \mathrm{r} 806$.

${ }^{37} I d . \$ \$ 1786-179 \mathrm{r}$.

${ }^{30} \mathrm{Id}$. \$r75I(b).
} 
Despite the language of Congress and the patent intent to encourage and support a rehabilitation program, limitations are further implicit in the wording of the Act, recognizable as conventional devices for the payment of claims against the govern-ment. The Commission from its inception was faced with the necessity of setting up the machinery and equipment of a claims agency. Forms were prepared by men in the United States accustomed to the mechanics of administrative bodies, but unfamiliar with the customs, experience, and language of the people of the Philippines. They were obviously ignorant of the fact, as evidenced by the forms which were prepared, printed, and circulated, that most of the eighteen million or more Filipinos residing in the Islands at the time did not use English as a language at all, and that most of the remainder would not be familiar with the idiom employed by : lawyers or government claims agents in the United States. ${ }^{40}$.

An American crew of skeleton proportions arrived in Manila in the autumn of : I946, occupying housing facilities principally in special quarters at the Manila Hotel, and using office space in a building. which had survived the general demolition. :This equipment was procured largely.through the zealous efforts of the Chairman and the Filipino member of the Commission. . Local help was recruited and performed most satisfactorily.

Since a distinction could be drawn between Titles I and III of the Act, relating respectively to private and public claims, separate divisions could be and were set up under the same administrative head for the implementation and execution of these programs. The differences between what on the one hand were essentially claims payments, relief, and welfare doles (although, to be sure, the actual payment of money in large amounts would be expected to have an effect on the economy of the country), and what on the other hand were contributions towards the physical rehabilitation of devastated areas, indicated throughout the history of the Commission the diverse patterns and philosophies implicit in the two approaches to war damage compensation.

\section{Private claims}

The language of the Act, despite its ostensible objectives in the field of rehabilitation, required the early adoption of rules and regulations which set up conditions, requirements, procedures, rules, and limitations sounding very much like those of claims agencies in the most orthodox tradition. ${ }^{11}$

The period for filing claims as required by the statute extended from March $x$, 1947 to February 29, 1948. The Bureau of Public Schools of the Philippines was employed to distribute forms to teachers who, in turn, were delegated the responsibility of issuing them to interested parties. The Commission maintained a publicity department, amply staffed, which gave widespread information in English and in

${ }^{40}$ See P.W.D.C. form 100 (basic claim forms); I00A (supplement for watercraft and automobiles); 300 (return receipt card); I-I (circular of general information). Filipinos employ 8 languages, 87 dialects.

${ }^{41}$ Rules and Regulations of the United States-Philippine War Damage Commission, II Fro. REg. 13337 (1946); 12 id. 813 (1947); 44 CODE FED. REgs. \$801-803 (1949). 
the local dialects through all available media, including newsprint, radio, and sound trucks. Branch offices in several localities in the Islands were installed and maintained not only to decentralize activities, but also (a) to offer facilities for filing in areas distant from Manila; (b) to assist the Commission in making investigations in larger claims and in special instances where circumstances demanded; and (c) to observe and record the reactions to the work of the Commission in local communities, which, in the scattered archipelago of the Philippine Islands with their diversity of races and tongues, naturally would be far from uniform. ${ }^{42}$

By the end of the filing period, approximately $1,250,000$ private property claims had been filed. Of these, more than one million had a claimed value of not more than $\$ 500$ each. Claims having a claimed value of more than $\$ 50,000$ each numbered less than 1700 .

The vast volume of individual cases made impossible the careful and conventional claims procedures originally contemplated by the American personnel which in large proportion had been recruited from Washington agencies dealing with claims against the government. The respect of the Commission for the cautious approach which was obviously favored by many legislators in dealing with the Philippines notwithstanding, no investigation worthy of the name could be made of all of the smaller individual claims. The obstacles became very tangible in dealing with remote territories, broken down transportation facilities, and ignorant, often illiterate, claimants.

Every element considered, the incidence of fraud was probably no greater than is assumed as a calculated risk in the adjustment of claims by insurance companies and other claims agencies in the United States during peace times. It is almost accepted practice for claimants to ask for more than they hope to recover. A reasonable degree of exaggeration must be overlooked in very much the same way as civil courts regard the inflation of damages claimed in an accident case beyond what the plaintiff hopes to recover. The excessive ad damnum is taken with a grain of salt, but is not ordinarily held to be prejudicial..$^{43}$

In the early record of the Commission an indication can be found of what any effort to make individual personal checks and investigations of claims might have

45 There are 7083 islands in the Philippines; three main racial groups-Negrito, Indonesian, Malay. Branch offices were maintained in: Baguio City; Cagayan; Cebu City; Cotabato (Davao City); Iloilo (Bacolod City); Legaspi; Manila (Cabanatuan, San Pablo City); Tacloban; Tuguegarao; Zamboanga.

${ }^{3}$ Hunt, the American Agent reporting the American and Panamanian Claims Arbitration under the Conventions of 1926 and 1932, says (Report, p. II): "Experience has shown . . . that in practically every general arbitration some of the most persistent and most vehement claimants are those whose claims are shown by examination to be unfounded, either in fact or in law." Also see Hudson, op. cit, supra note 8: "The amounts claimed against States are easily exaggerated. A public purse always looms large in the eyes of a claimant. Hence the total of the awards made by a tribunal is frequently out of all proportion to the total amount of the claims presented to it. Following the Civil War in the United States, British claims were presented to the amount of $\$ 6,000,000$, but less than $\$ 2,000,000$ was awarded by a claims commission; French claims totaled $\$ 3,500,000$, but less than $\$ 650,000$ was awarded. The I868 American-Mexican Commission awarded less than one percent of the amount claimed by each Government from the other; the r9ro American-British tribunal awarded less than two percent of the amount of the American claims, and only four percent of the British claims.". 
entailed. The development of standard procedures for the settlement of the stupendous volume of claims of small size, without individual investigation, resulted in the gradual increase of the volume adjudicated from about 3,000 in July to $16,4 \mathrm{I} 4$ in November, 1947, with every prospect of a proportionate increase each month. Due to the disclosure in November, 1947 of evidence indicating the possible existence of fraud in several hundred small claims in a minor locality, the Commission decided to discontinue disposing of cases, however small, without individual check-up in the field. The volume of adjudicated claims dropped from about 6,200 in December, r947 to less than 3,000 in January, 1948, and to smaller numbers thereafter until the realistic policy of standardized examination of small claims without individual investigation, except in particular instances, was resumed. When the full impact of this policy was realized, claims settlement zoomed so that by December 3I, 1949 the Commission had processed 927,000 small claims.

More fundamental and more immediate than the adoption of measures to counteract attempts at fraudulent enrichment was the development of standards of value which would, in a practical sense, contemplate the restoration of property destroyed or damaged during the war. If there was any substance in the rehabilitation aspect of the work of the Philippine War Damage Commission, such an objective had to enter into its deliberations.

The Act imposed the restriction of paying to successful claimants the actual cash value of property at the time of loss or injury; or in the alternative, the cost of repairing, rebuilding or replacing the same with other property of like quality; whichever was less. The technicians of the Commission undertook, through exhaustive research, to determine valuations of types of articles which were recurrent in claims and to prepare tables of depreciation. Thus, if a printing press had been acquired new in 1935 at a certain price, its valuation at the time of loss could, according to the tables prepared by the Commission, be determined. The more complicated problems arising in connection with growing crops, like sugar, rice, tobacco, hemp, cocoanuts, and corn, indigenous to the Philippines, or with animals in being, but not born before December 7, I941, presented categories of head-splitters which were weighed by the Commission after hearings of interested parties, as expediency dictated and the limitations of the Act required. The question remained open always of whether the true aims of rehabilitation are being observed when the value of property at the time of loss, or the cost of repairing, reconstruction, or replacement, whichever is less, is the basis of compensation. Doubts become accentuated when there is adopted as a basis of compensation a formula for settlement establishing not even the cash value at the time of loss or damage (which, in all instances in the Philippines, was less than the replacement value), but reduced values determined according to preconceived tables of depreciation. ${ }^{44}$

It must be said in fairness that the Philippine War Damage Commission was

"For a discussion of values in separations, sec Gide, The Indemnity for Reparations, 104 Annuls 340, 342 (November, 1922). 
restricted in the first instance by law from awarding replacement values if they were more than the cash value at the time of loss. But, it is submitted, the Commission, in adopting rigid standards which embraced; where applicable, the use of depreciation tables or predetermined standard values for frequently recurring items of the lowest figure consistent with any degree of fairness, went farther than was required. It is safe to say that in connection with the compensation for loss or damage in privately owned property, no practical consideration was given to reconstruction or replacement values. Add to this the obstacles in the way of making restitution in kind of lost property and you find. a situation where true rehabilitation is a remote concept.

The most common claims before the Commission were based upon total or partial destruction of small homes; simple tools; work animals, mostly carabao, pigs, chickens; and stocks of wood. These were usually inadequately identified. Not all of the claimants had the patience or artistry of one from Dipolog, Zamboanga, who not only enumerated his personal belongings and described them in detail, but portrayed them with rare skill in drawings, some of them colored. He elaborated upon each item with such detail as "muslin (cocoa) blanket bedspread combination, beautifully embroidered by my wife; when we arrived in Cebu the work was done; she was a school teacher, but when I took her to Cebu she stayed at home to comfort her life companion."

Obviously, restoration in kind in these instances was a virtual impossibility, and in the case of antiquated equipment, was not even desirable. The only acceptable method of coping with the problem of compensation for such losses was to develop a set of values for the smallest and most frequently mentioned items, a rule of the thumb, as it were; and for the valuation of more considerable property, a system of appraisal worked out specifically for real estate, machinery, equipment, and merchandise; and to pay the claimants in cash.

Congress, in considering and adopting the war damage legislation under which the Commission functioned, placed much emphasis upon the rehabilitation program and the devotion of the funds provided to the rebuilding of a devastated area, but, nevertheless, recognized that the the implementation of such a program would defy the best efforts of an administrative agency. In committee the original proposals were amended as follows:

PROVIDED, That if the Commission determines it is impossible for any reason beyond the control of the claimant, or is impractical to rebuild, replace, or repair the lost or damaged property, the Commission may make payment to the claimant without making said requirement: PROVIDED, however, That, as a condition to the making of such payment, the Commission shall require that the whole of such payment shall be reinvested in such manner as will further the rehabilitation or economic development of the Philippines; AND PROVIDED further, That nothing in this subsection shall preclude the partial payment of claims as the rebuilding, replacing, or repairing of the property progresses. 45

${ }^{45} 60$ Stst. 131, as amended, 60 STAT. 805, 50 U. S. C. App. 81755 (Supp. 1950). 
The Commission has reported that a survey which it conducted demonstrates that the little claimant who received an award is rehabilitating himself and his family with war damage payments; that he is buying tools and work animals and repairing his home and his store, endeavoring to reconstruct himself as the mainstay of an agrarian land.

In the period July I to December I, I949, the Commission made an analysis of the use which large claimants-industry, business and agriculture and all of those who contribute most to employment and general rehabilitation-are making of their payments. Without question, they, like Juan de la Cruz, ${ }^{46}$ have utilized the money they have received to benefit materially the processes of economic recovery, although the funds have been far from sufficient to provide complete restoration of lost or damaged property. ${ }^{47}$

Further, it is reported that in small claims processed by December 31, r949, the claimants had been paid approximately $\$ 127,085,000$ of the total $\$ 400,000,000$ authorized in the Act. Of approximately 1,000 claims having a face value of more than $\$ 50,000$ each completed by December 3r, 228 were disallowed because of ineligibility of claimants under the law, and the remainder by allowance and initial payments aggregated $\$ 35,000,000$. The Commission announces that actual reinvestment of this group in the economy in the Philippines was estimated to be $\$ 116,000,000$ during the same period. The survey also disclosed that 274 claimants who were paid a total of something less than $\$ 27,500,000$ had actually reinvested $\$ 108,000,000$ prior to award by the Commission. It would not be wide of the mark to conclude that much more than this amount was invested in postwar Philippine construction and business before the Commission got around to making payments.

Despite the best efforts of the Philippine War Damage Commission resulting in some sort of record attached to the completion of its task in settling almost 1,250,000 private claims before the expiration of the time limit set by Congress, and with less administrative expense than authorized, there was an essential lack of realism in the whole operation measured by the requirements of a true rehabilitation program. Among many elements in the account, which we need go no farther to find than the experience of the Commission in handling private claims, are the following:

$\therefore$ (I) The law itself, although sounding in language of rehabilitation, actually imposed the restrictions of a claims agency.

(2) There were obstacles even to the adoption of ordinary claims procedures because of the volume and small size of the claims which actually called for relief or welfare donations.

(3) The specific requirement that compensation should be made for property lost or damaged on the basis of the cash value at the time of loss or damage or replacement or reconstruction value, whichever was less, disregarded fundamental principles of rehabilitation which have to do primarily with replacement, restoration, reconstruction, and improvement. To this was added the additional limitation of

"The "John Smith" or little man of the Philippines.

4 United States-Philippine War Damage Commission, Seventh Seminnnual Report for Pumod Ending December 31, 19493 (1950). 
the procedures of the Commission which, in the case of very small items, used low standard values, and in the case of more considerable property, applied tables of depreciation which reduced the awards materially from original costs to unrealistic values at the time of loss or damage.

(4) The language of the law authorizing replacement or restitution in kind was not implemented in practice, due to the impossibility of realization under postwar conditions. The qualification in the law permitting payment in cash, without even requiring the replacement of property with the funds awarded, simply recognizes the obvious. The additional condition imposed upon the Commission, that it shall require the whole of the payments to be invested in such manner as will further the rehabilitation or economic development of the Philippines; to be effective obviously would require such policing as the Commission had neither the time, the funds, nor the facilities to control.

(5) Payments under the word and spirit of the Act had to be made to innocent victims or to their heirs who might leave the Philippines, or conceivably never lived there.

(6) Despite the time record of the Commission, it still remains a fact that two to five years or more elapsed from the time of the loss or damage to the date of the award. Moreover, the payments above $\$ 500$ made on larger claims were diminished in three ways: (a) the award, due to valuation procedures of the Commission, ordinarily reflected a great reduction from the claimed amount; (b) under the law an automatic reduction of 25 per cent of the excess over $\$ 500$ was made; (c) initial proportionate payments on awards above $\$ 500$ amounted to 30 per cent and it has been predicted by the Commission that about $5^{\circ}$ per cent in all might be expected in final computation.

(7) Since the total physical damage to property in the Philippines has been estimated at from $\$ 800,000,000$ to $\$ 1,250,000,000$ (and by some at two billion dollars). the amount of money made available in the first place was inadequate to attack the job which the United States protested it would undertake.

(8) The functions and performance of the War Damage Commission were not integrated closely enough with other Philippine rehabilitation efforts. A number of assistance programs were going on at the same time. Years after the end of the war the Philippines are still in bad shape economically, and by standards of the United States, far from satisfactorily advanced physically.

\section{Public Claims}

Of the amount of I20 million dollars allowed by the Congress in Title III of the Act for the restoration and improvement of public property and essential public services in the Philippines, sixty-three million dollars was allocated to rehabilitation of public roads, public health, inter-island commerce, air navigation, and coast and geodetic surveys, each, as has been indicated earlier, under the administration of an agency of the United States within the jurisdiction of which such efforts would 
ordinarily fall. Representatives of these arms of the United States Government have been located in the Philippines to complete work which is authentically rehabilitation.

The Philippine War Damage Commission was allowed 57 million dollars "to compensate the Republic of the Philippines, the provincial governments, chartered cities, municipalities and corporations wholly owned by the Commonwealth of the Philippines ... for physical loss of or damage to public property in the Philippines" occuring within the same time limits, and as a result of the same perils of war, as designated for private property losses. ${ }^{48}$

The physical improvement of public property resulting from the direct efforts of agencies of the United States is obviously easier to detect than the recovery of the economy and even tangible incidents of private life. Roads were repaired, transportation services restored, under the very eyes of observers. Debris was swept from the harbor by the strong arms of men paid by the United States. Health services were revived to serve daily needs of the Filipino people. The War Damage Commission has appropriately placed upon principal Philippine schools and government buildings reconstructed with the aid of the United States plaques inscribed as follows: "Rebuilt with the aid of the people of the United States of America under the Philippine Rehabilitation Act of 1946."

Procedures in the rehabilitation of publicly owned property adopted and employed by the War Damage Commission from the beginning reflected three distinct basic policies. First: the Commission would not do the work itself; second: the Commission would not pay the entire sum of money awarded for the repair or reconstruction of a damaged or destroyed building directly to the Philippine Government to be spent by it; third: the Commission would pay to authorized agencies or subdivisions of the Philippine Government the money awarded to specific projects suggested by the Philippine Government, only as their progress and completion were verified by representatives of the Commission. Pursuant to these principles and practices, the Philippine Government presented to the War Damage Commission claims totalling approximately I9o million dollars. Priorities were adopted in making awards according to the following sequence: (I) hospitals and municipal water works; (2) schools; (3) government buildings. Again, despite the considerable expense to which the United States Government consented to go in its program of assistance, the amount of 120 million dollars (of which 57 million dollars was allocated to the War Damage Commission), was appreciably deficient. This is true even giving effect to the additional grant of surplus materials "to aid in repairing and replacing buildings . . . works, utilities, equipment or other property." ${ }^{40}$

The Philippine Government undertook and is completing restoration projects on a much larger scale, but it must be recognized that the contributions of the United States Government and the stimulation they furnished, particularly through the

${ }^{48} 60$ Stat. 136, 50 U. S. C. App. 5 r784 (Supp. 1950).

${ }^{10} 1 d . \$ \$ 1771-1776$. 
orderly processes, planning, and supervision afforded by representatives of the War Damage Commission, were of inestimable help, and probably account for some very substantial accomplishment not traceable to any other source..$^{50}$

As early as destruction in the principal cities of the Philippines was viewed, it became apparent that the amount of money which the United States could or would donate towards physical rehabilitation would not be enough to accomplish the full job. Moreover, the pattern of distribution followed there may have been suited to the Philippines, but may never be applicable to another instance of the repair of war damage. The Philippine Government had become independent; it reserved the right to develop its own program of reconstruction, embracing improvements, changes of sites, and re-emphasis of projects according to overall plans of its own. Lastly, there is a question whether funds for rehabilitation should not have been turned over to the government suffering the damage to be expended by it without supervision or verification, a course which, for the Philippines, is not now open to review, but which may be considered in connection with future undertakings.

The writer has entertained little reservation in questioning the efficacy of the award of small welfare payments or even larger amounts in partial reimbursement for losses of private property, as a constructive factor in overall rehabilitation. $\mathrm{He}$ is ready to admit, however, that the dual program forced upon the War Damage Commission by the Act had the healthy effect of placing in comparable perspectives war damage money grants and public property rehabilitation. The implementation of the latter service, regardless of methods and amounts, appeared tangible, constructive, and durable. Improved planning and more advanced techniques of operation would serve to bring about an even better result.

\section{III}

\section{Correlation of War Damage Compensation and Rehabilitation: Conclustons and Prospects}

For the future which is now foreseeable there will be a measure of expedient application of the historical pattern in the settlement of war claims following lines

${ }^{80}$ Of the total amount of 57 million dollars allocated to the. War Damage Commission for the program of restoration and repair of public property, $\$ 1,700,000$ was set aside for estimated administrative expense. The balance determined by the Commission in conjunction with the Philippine Government was apportioned as follows:

liem Per cent of Allocation

Schools .................62.4

Hospitals and dispensaries...... 8.3

National government buildings.... I2.3

Provincial and Municipal

government buildings....... 7.4

Waterworks and

irrigation systems........ 5.6

Government corporations $\cdots \cdots \frac{4.0}{100.0}$

$\begin{array}{cc}\text { Allocated Amount } & \text { Per cent of Estimated Loss } \\ \$ 34,546,698.87 & 35.8 \\ 4,571,010.10 & 91.9 \\ 6,810,747.89 & 34.0 \\ 4,081,701.15 & 13.3 \\ 3,089,841.99 & 59.5 \\ 2,200,000.00 & 17.9 \\ \$ 55,300,000.00 & \end{array}$

Sec Seventi Semiannual Report of the United States-Philippine War Damage Commishon, DeCENIBER 31, 194922 (1950). 
of (a) reparations from losing belligerents; (b) payment for property commandeered, confiscated or requisitioned under pressure of necessity; (c) indemnities and the adjustment of losses under treaties or other international agreements, whether on a national or territorial basis.

The concern with which the government of the United States has addressed itself to the ethical elements in war damages-justice and humanity-has not been diluted by considerations of material reward or reimbursement from other governments. ${ }^{51}$ The big fact is there-that not much is to be hoped for in the way of indemnities or reparations for the very practical reason that none of the enemies of the Allies is solvent or likely to be for a long time. Still further, with the kind of war which is waged in the modern era, the enemy at the time of victory becomes reduced to a position where it is actually the charge of a victorious opponent, and in the name of humanity and sound business, if you please, demands its own rehabilitation at the expense of the rest of the world. It goes also without saying that despite encouraging signs of recovery among the Allies of the United. States, it is too early to expect scientifically balanced international adjustments of war losses among them; the burden will ever fall on the most affluent.

A decline in international principles affecting requirements for the declaration of war, the rules governing the treatment of prisoners, and the adjustment of losses afterwards, has been brought about by each successive struggle through the process of violation by one side and retaliation by the other. Superficially, there have been accretions to the body of understanding and information in the subject. of international law, and new techniques have been adopted governing reștitution, reconstruftion, and rehabilitation due, as an anomaly, to the: corroding processes. of war. . In the Philippines, as has been pointed out, the United States, under no legal compulsion, and largely without precedent, made a contribution of sizable proportions to correct the dislocations brought about by warfare.

It is true that as far as the Philippine experience goes there have been demonstrated deficiencies in legislation and perhaps in administration in the earlier stages of the program. These resulted from (a) inexperience implicit in the novelty of the plan; (b) concerns of public relations which led to confusion between what were essential welfare payments to the litte man and financial reimbursement to sufferers of more considerable property losses; (c) local peculiarities of language, custom, and geography. $\ldots, \cdots, \ldots$

The following considerations which the writer 'makes bold to express would not have sounded as trite.a few years ago as they do now.

Only cooperative international action appears to be an effective instrument of progress towards peace. 'It is not just ethically correct, but economically sound,

${ }^{52}$ Converisely, in the case of the International Claims Settlement Act, the United States Government proposes to obtain settlement fromi countries which have nationalized private property or otherwise caused losses to nationals of our country before awards will be made to-claimants for these losses. So far a settlement of $\$ 17,000,000$ has been made with Yugoslavia; others are expected, although not immediate in time, with Poland änd Czèchioslovakia. 
that those most fortunately situated in worldly goods should make their resources partly available to the backward and those denied equal gifts and opportunities. It is assumed that this principle will be supported only to the extent that it is consistent with a sane regard for conserving those resources upon which the prosperity of the favored nation is based.

The adjustment of losses after a war will have to take into account direct rehabilitation, irrespective of responsibility and beyond the limits of any plan which, like insurance, contemplates only monetary awards to individual sufferers. The kind of war damage compensation thus envisioned would be free from the detailed concerns incident to a program of war damage compensation which, in the case of the fraudulent, is unjustified, and in the case of real victims, often has been hopelessly inadequate. It does not provide, in the category of business and private property losses, for examination, investigations, appraisals, standard values, and other techniques, which are suitable to adjustment in avenues of commerce, but not in the field of international post-war recovery and reconstruction.

' The future of war damage compensation might follow paths which at the moment may seem to be laid along very ambitious lines and in at least some directions may meet with obstacles of unpopularity and skepticism and fear. These paths in any event would have distinguishable and desirable characteristics, some of which may be suggested, even at the risk of approaching controversial territory.

First: The area of war losses having been identified, the nations participating in the hostilities resulting in such damage must immediately set up an agency to determine (a) the extent of the damage; (b) a formula for immediate relief and recovery on the basis of expediency; ${ }^{52}$ (c) an overall plan for rehabilitation and improvement.

Second: The obligation to finance the rehabilitation program shall be independent of blame. Industry and government long ago discovered that in such socially significant areas as .workmen's compensation (including occupational illness as well as accident), unemployment and.old age security, specific causation or fault should be disregarded and benefits awarded as a part of the expense of doing business or conducting an organized society. Commercial and political entities underwrite restitution, relief, and rehabilitation, on a minimal basis, to be sure, as an incident to the vagaries of human existence. In international affairs, so long as warfare persists as an institution, and the kind of war is promised which is no respecter of noncombatant person or property, recovery and rehabilitation are also common, group responsibilities.

Third: The budget necessary to insure the completion of overall rehabilitation

\footnotetext{
62 The writer was engaged in the efforts of the United States Government directly following the reoccupation of the Philippine Islands to bring immediate relief to war sufferers and to reestablish the channels of ordinary living and trade. These efforts, delegated officially first to the Forcign Economic Administration and then carried on in detail by the U. S. Commercial Company, a subdivision of this Administration later taken over by the Reconstruction Finance Corporation, were supplemented in the carly post-war era by very effective private relief bodies. All of this was quite apart from the rehabilitation program covered by the Act of 1946 .
} 
will not depend upon the precise nature of the items lost, their cost, deprecialiun, replacement value, and other traditions in the school of claims adjustment. Nu isolated instance of fraud or exaggeration will be entertained as a distraction. The fractures of war will be reduced through rebuilding. Rehabilitation to be constructive must be along modern designs with a view to improvement rather than restoration of the status quo ante bellum. The nipa hut ought to have been replaced by livable dwelling quarters; the outhouse or tree-stump eventually has to give way to plumbing and a septic tank.

Fourth: Commencing on a physical level total reconstruction will entail as a normal consequence sound economic improvement extending into the life of each member of the community. Therefore, a loser of a hut or a carabao, although he may feel injured when denied restitution in kind or a cash equivalent, is actually a joint beneficiary with his fellow-men of the boons of modern planning-adequate housing facilities, up-to-date equipment, a generally enhanced economy with expanded opportunities for every individual.

- Fifth: In the case of Korea, for instance, it is a remote hope that those whom we would adjudge malefactors will pay for the damage done during the invasion if the South and the battle for the North. Nonetheless, it is 'universally' conceded that there must be (a) immediate relief measures, and (b) a total rehabilitation program to be adopted, implemented, and initiated as soon as possible. No one at this stage of world development is cynical enough to suggest that all we need do in this unhappy country is to pay, after meticulous investigation; the sums.of money reprel senting the depreciated value of property destroyed or damaged, or 'to undertake to restore it to its former condition which, except in the cases of a few buildings and installations, would mean a long step backwards.

Sixth: The United States is the repository of a considerable portion of the usable wealth of the world as 'well as of most of the remaining hopes of mankind. In connection with postwar' restoration it already has assumed the heaviest burden; irrespective of fault or responsibility:. The idea of doing most of the financing of wholesale rehabilitation in not only Korea but possibly Indonesia, Indo-China, Tibet; Persia, and other remote corners of the earth where the allied forces of freedom 'may be engaged by their challengers, may startle not only the conservative among out citizens but sound statesmen and international: lawyers whose approaches have been conditioned to orthodox concepts of reparations, indemnities, and the payment of mixed claims in orderly procedures.: If there were in existence an international fund; built up over the years, analogous to insurance deposits, against the casualty of : war; resistance might not be great. The lack of such a fund, however, does not diminish the necessity or responsibility for the same.kind of assistance as would be extended throingh insurance benefits: We have already adjusted ourselves to an agreeable reception of a law which permitted outright grants to the Philippines of more than half a billion dollars. Under the Marshall Plan and international defense agreements' 
we are committed to the expenditures of billions more without any hope of direct return, but with boundless confidence that we shall be rewarded by the betterment of the world of which we are a part. It is no great step in advance of what we are doing to subscribe unreservedly to the principle that rehabilitation of war damaged countries is a world responsibility which we shall share within the limits of our resources. It is not implied that the rehabilitation of any one country will be at the expense of the debilitation of another.

Seventh: The logical agency to plan, implement, and carry out a program of rehabilitation anywhere in the world is the United Nations..$^{53}$ If in the distant future there is to be an adjustment on the basis of blame or proportionate responsibility, it should be effected under the auspices of this convenient international mechanism. Any reserves which might be set up in peace times to cover the casualties of war should be assembled and safeguarded by a common instrumentality the strengthening of which by any means is a gesture towards peace. This is not the place to make specific recommendations, but the generalities propounded should be sufficiently imperative to set machinery in motion for fabricating workable plans. ${ }^{54}$

In the course of this discussion an effort has been made to correlate concepts of war damage compensation and total rehabilitation. Since the need for some form of adjustment of individual war claims along traditional lines will probably persist indefinitely, and since, moreover, a backdrop of historical activities may help a picture of the future, a general survey was first attempted.

The Philippine Rehabilitation Act of 1946 and the experience of the War Damage Commission were then presented for the object lessons they contain. It is true that in the case of the Philippines there were special pressures due to a long and unusual relationship. Many valid generalities, nevertheless, may be drawn from that experiment.

Hereafter, isolated domestic legislation donating money, property, and services should be avoided. Haphazard grants, gifts, and easy loans, made on the basis of politics, public relations, and even humanity, are essentially ineffectual in a genuine rehabilitation program. The combination of welfare payments or doles, relief

${ }^{53}$ UNESCO already has taken jurisdiction in relief and rehabilitation of war stricken areas.

"After this text had been prepared the naming of a civilian to rebuild Korea under United Nations auspices was recommended at Lake Success by a representative of the United States. The subject received widespread press notices among them the following which appeared in issues of October 17, 1950:

Washington Evening Star: "The United States proposed today that the United Nations appoint a supreme civilian boss to direct Korea's multi-million dollar economic rebuilding."

N. Y. Times: "No decisions have yet been taken on how the financial burden shall be borne. But the U. S. - because it is the only power that can spare substantial resources to do the job-will play a dominant part in the program. Last week President Truman said, 'The United States will carry its full share of this load.' "

The Christain Science Monitor: "President Truman, before leaving for his Wake Island meeting with Gen. Douglas MacArthur, approved a relief and rehabilitation program for Korea of nearly $\$ \mathbf{I}$ billion, it was learned.

The program, as envisaged by the President, would call for establishment of a war damage and recunstruction corporation under United Nations auspices, to which the United States would contribute between $\$ 200,000,000$ and $\$ 300,000,000$ annually during the next three years." 
measures, war damage settlements, and rehabilitation projects in one great hopper, is bound to lead to confusion and disappointing results.

What is indicated in the dangerous cases of war damage and destruction is a remedy, consistent with advances in world thinking, in the form of a systematic provision for total adjustment of total losses occasioned by total wars, governed wholly by the techniques of rehabilitation.

Collective compensation packaged in repair, reconstruction, and improvement of war devastated regions is an immediate objective which does not concern itself with individual indemnities for the loss of private possessions. The aggregate benefits of rehabilitation inure to the world and may be derived only from broad, progressive, and concerted action by all interested groups. Such action requires a common instrumentality which is now available in the United Nations Organization. This body, in the face of doubts and cynical assaults which have questioned its rights to survive, has successfully answered the call of war; given half a chance, it can do as well in response to the summons to compensate war damage through rehabilitation. 